\title{
鿻 \\ EPISTEMOLOGI YANG MENGHERMENEUTIKA MENURUT RICHARD RORTY
}

\author{
M. Ied al-Munir \\ IAIN Sulthan Thaha Saifuddin Jambi \\ Ied_munir@yahoo.com
}

\begin{abstract}
Abstrak
Tulisan ini memiliki tujuan untuk memberikan deskripsi atas penolakan Rorty terhadap epistemologi dan kemudian menggantikannya dengan hermeneutika. Penolakan Rorty dimaksud sebenarnya adalah sebuah bentuk kritikan Rorty atas epistemologi fondasional yang berakar pada pemikiran-pemikiran Descartes, Locke, dan Kant. Epistemologi tidak harus dimengerti secara sempit dalam pengertian epistemologi fondasional menurut Rorty. Dan Rorty sendiri sesungguhnya sedang berepistemologi ketika menolak epistemologi fondasional, karena Rosty berkecimpung dalam dunia pengetahuan.
\end{abstract}

\begin{abstract}
HERMENEUTICALY EPISTEMOLOGY ON RICHARD RORTHY PERSPEKTIVE. This paper aims to provide a description of Rorty's rejection on epistemology and then replace it with hermeneutics. Rorty's rejection is actually a form of criticism by Rorty on foundational epistemology that is rooted in the ideas of Descartes, Locke, and Kant. According to Rorty, Epistemology should not be narrowly understood in the sense of foundational epistemology. And Rorty himself actually was having an epistemology paradigm when rejecting foundational epistemology, because Rosty involved himself in the world of knowledge.
\end{abstract}

Kata Kunci: epistemologi; hermeneutika; fondasionalisme; antifondasionalisme. 


\section{A. Pendahuluan}

Puluhan tahun yang silam, pada saat empirisme logis masih sangat berpengaruh, baik dalam dunia filsafat maupun dalam disiplin ilmu-ilmu sosial, terdapat kesan bahwa inti filsafat yang sebenarnya adalah epistemologi. Akan tetapi, dewasa ini, situasinya berubah total dan berbalik arah, epistemologi telah mendapatkan kritikan dari segala sisi. Salah satu kritikan dan faktor terpenting yang memicu dimulainya diskusi kritis atas epistemologi adalah terbitnya karya Rorty berjudul Philosophy and the Mirror of Nature tahun 1979. Di dalam buku in dijelaskan bahwa fondasionalisme Locke, Descartes dan Kant pada dasarnya merupakan suatu pembakuan epistemik tentang proses mental yang terjadi dalam akal budi di mana benak manusia mampu memperoleh gambaran obyektif apabila melepaskan diri dari kebersatuan sosial. ${ }^{1}$

Sejak terbitnya buku Philosophy and the Mirror of Nature inilah, hampir menjadi semacam ortodoksi bahwa segala bangunan pemikiran yang didasarkan pada pemikiran-pemikiran Descartes, Locke dan Kant yang diabadikan sampai abad ke-20 adalah suatu kesalahan mendasar. ${ }^{2}$ Rorty melihat inti permasalahannya terletak pada karakter fondasional dari epistemologi. ${ }^{3}$ Dalam perspektif fondasional ini diyakini bahwa segala pengetahuan ilmiah positif membutuhkan satu disiplin yang dapat mengecek dan mendasari klaim-klaimnya tentang kebenaran. Disiplin ini adalah epistemologi. Suatu ilmu dapat dikatakan sahih bila penemuan-penemuannya dapat memenuhi segala bentuk pengujian epistemologis. Epistemologilah yang akan menyatakan dasar kesahihan sekaligus batas kesahihan pengetahuan. ${ }^{4}$ Epistemologi dengan karakter fondasional ini sebenarnya bermasalah karena epistemologi secara umum diyakini tidak bergantung pada ilmu-ilmu empiris. Argumen mengenai dasar kesahihan pengetahuan dipandang tidak mungkin bersifat empiris.

${ }^{1}$ Donny Gahral Adian, Menyoal Objektivisme Imu Pengetahuan: dari David Hume sampai Thomas Kuhn, (Bandung: Teraju, 2002), h. 97.

${ }^{2}$ I. Bambang Sugiharto, Postmodernisme: Tantangan bagi Filsafat, (Yogyakarta: Kanisius, 1996), h. 68.

${ }^{3}$ Richard Rorty, Philosophy and the Mirror of Nature, (NJ: Princeton University Press., 1979), h. 132.

${ }^{4}$ Sugiharto, Postmodernisme: tantangan ..., h. 68. 
Tulisan ini merupakan elaborasi sederhana tentang kritik Rorty terhadap epistemologi di atas yang bila dicermati lebih mendalam adalah bukannya tentang penolakan Rorty terhadap epistemologi secara umum, karena Rorty sendiri sebenarnya sedang berepistemologi, tapi tentang penolakannya terhadap epistemologi fondasional, terutama yang berpijak pada pemikiran-pemikiran Descartes, Locke dan Kant.

\section{B. Kehidupan Richard Rorty}

Richard McKay Rorty (1931-2007) adalah seorang filsuf dan intelektual Amerika terkemuka. Di awal karir filosofisnya, Rorty adalah penerus Mazhab Pragmatisme, terutama dari Dewey dan Peirce. Ini terlihat dari buku Philosophy and the Mirror of Nature (1979) dan Consequence of Pragmatism (1982). Kedua buku ini menentang komitmen filsafat Barat terhadap gagasan-gagasan absolut tentang kebenaran. ${ }^{5}$ Rorty mengikuti Dewey dalam menyerang pandanganpandangan mengenai pengetahuan, pikiran, bahasa dan kebudayaan dengan pendekatan menarik yang menggambarkan berbagai argumen dan pandangan sejarah filsafat dari sumber yang merentang mulai dari Heidegger dan Derrida sampai dengan Quine dan Wilfrid Sellars.

Pragmatisme Rorty melampaui Dewey karena adanya tambahan analisis filsafat analitik dan diperkaya lagi dengan metode ilmiah dari Kuhn. Selain itu, Pragmatisme Rorty juga hanya memiliki sedikit hubungan langsung dengan Empirisme. ${ }^{6}$ Menurut Rorty, bahasa dan pemikiran merupakan alat-alat yang dapat dipakai untuk mengopi realitas, sehingga keduanya bukan realitas pantulan seperti pada pandangan filsuf yang lainnya. Posisi-posisi filosofis yang khas Rorty adalah apa yang mungkin disebut antiisme, posisi-posisi yang didefinisikan utamanya dengan apa yang ditolak. Dalam epistemologi, Rorty menyokong anti-fondasionalisme dan anti-realisme. Sementara dalam meta-etika, Rorty mendukung anti-antirealisme. Rorty memuji pragmatisme sebagai filsafat yang dapat membersihkan jalan bagi cara-cara baru berpikir yang dapat

${ }^{5}$ Stuart Sim, the Routledge Companion to Postmodernism, (London and New York: Routledge, 2001), h. 351.

${ }^{6}$ Peter Godefrey-Smith, An Introduction to the Philosophy of Science: Theory and Reality, (Chicago: the University of Chicago Press, 2003), h. 239. 
dipergunakan untuk mengurangi penderitaan dan untuk membantu menemukan apa yang diinginkan dan bagaimana memperolehnya.

Rorty menempuh pendidikan tingginya di University of Chicago dan Yale University. ${ }^{7}$ Di kedua perguruan tinggi ini Rorty memperoleh banyak hal tentang sejarah filsafat, pragmatisme dan filsafat tradisional yang dominan di Amerika pada pertengahan pertama abad ke-20. Ini juga yang kemudian mengantarkan Rorty untuk memenangkan penghargaan the Allegiance of Younger Philosophers. Sejak tahun 1960-an, Rorty mulai memublikasikan artikel-artikel dan reviu-reviu tentang banyak masalah filsafat, tentang filsafat dari banyak pemikir lainnya seperti Whitehead, Dewey, Royce, Austin dan Wilfrid Sellars, dan juga tentang isuisu metafisikal yang muncul dari multiplisitas konsepsi-konsepsi filsafat dan metode-metodenya. Kesemuanya dapat ditemukan dalam antologi The Linguistic Turn: Recent Essays in Philosophical Method (1967).

Dalam rentang akhir 1960-an sampai dengan 1970-an Rorty dikenal sebagai seorang kontributor terkemuka dalam pembicaraan tentang filsafat pemikiran, metafisika, epistemologi dan filsafat bahasa. Rorty menopang posisi-posisi radikal di tiap bidang-bidang ini dan menggambarkan serangan-serangan terhadap tradisi filosofis Heidegger, Derrida, Wittgensten periode belakangan dan khususnya Dewey. Rorty mencapai peringkat pertama di antara para filsuf Amerika dan mendapatkan perhatian internasional di luar lingkaran filsafat dengan publikasi atas karya utamanya Philosophy and the Mirror of Nature (1979). Buku ini membawa semua garis pemikirannya dalam suatu usaha agar para filsuf dan orang-orang yang melihat filsafat memberikan otoritas kepada aktivitas kultural mereka sendiri dan meninggalkan pandangan-pandangan tentang pengetahuan, pikiran, bahasa dan budaya dari gerakan filsafat analitis yang mengklaim telah meletakkan filsafat pada jalan yang benar atas ilmu pengetahuan. Lantaran itu, Rorty kemudian dalam banyak artikel, reviu dan perkuliahan memperluas serangannya terhadap tradisi filsafat tadi. Rorty membela versi pragmatismenya sebagai cara terbaik yang dapat terus ditekuni para filsuf.

${ }^{7}$ Ali Mudhofir, Kamus Filsafat Barat, (Yogyakarta: Puastaka Pelajar, 2001), h. 441. 


\section{Pemikiran Filosofis Richard Rorty}

\section{Metafilsafat}

Rorty membagi tiga model filsafat yang paling menarik dari para filsuf kontemporer, yakni filsafat-filsafat scientistic (Carnap), poetic (Heidegger), dan political (Dewey). Rorty sendiri mendukung model yang terakhir sebagai model yang paling cocok dengan Pragmatismenya.

Menurut Rorty, para filsuf harus berusaha mengikuti dan menyamai kebajikan-kebajikan moral yang telah ditunjukkan oleh komunitas-komunitas ilmiah, namun dengan membuang kepercayaan dalam metode ilmiah sebagaimana dalam metode filosofis. Para filsuf harus membantu perkembangan penemuan metapora-metapora baru. Filsafat harus berubah menjadi hermeneutika, untuk membantu area-area yang berbeda tentang budaya dan untuk membuat kontak dengan masing-masing yang lainnya serta untuk menyortir konflik-konflik. Tugas yang sangat penting sekarang adalah untuk membersihkan filsafat yang buruk di masa lalu dan ide-ide buruk pemikiran. Sederhananya, filsafat adalah apa yang bisa dilakukan untuk membuat orang-orang lebih bahagia. Sebagaimana saran-saran metafilsafatnya, posisi-posisi filosofis khas Rorty adalah apa yang mungkin disebut "anti-isme". Dalam epistemologi, Rorty menyokong anti-fondasionalisme, dalam filsafat bahasa anti-representasionalisme, dalam metafisika antiesensialisme dan realisme dan anti-realisme, dalam metaetika ironisme. $^{8}$

Menurut Rorty, filsafat modern telah mengambil bentuk epistemologi atau teori pengetahuan, ${ }^{9}$ padahal yang diperlukan bukan epistemologi, tapi hermeneutika. Bukan sebagai pengganti yang semula diemban epistemologi, namun justru sebagai upaya yang mengungkapkan harapan agar fungsi epistemologis tidak lagi dirasakan perlu. Hermeneutika dimaksudkan sebagai aktivitas pemaknaan wacana dalam percakapan budaya manusia.

${ }^{8}$ Michael David Rohr, "Richard McKay Rorty” dalam Routledge Encyclopedia of Philosophy, Version 1.0, (London and New York: Routledge, 1998).

${ }^{9}$ Michael Williams, "Richard Rorty", dalam A Companion to Analytic Philosophy, A.P. Martinich dan David Sosa (ed.), (Massachusetts: Blackwell Publisher In., 2001), h. 428. 
Hermeneutika memahami hubungan antara macam-macam wacana sebagai alur percakapan. Percakapan itu tidak mengandaikan adanya matriks disipliner yang mempersatukan para pembicara. Harapan tercapainya kesepakatan ini tidak berarti harapan untuk menemukan suatu dasar pijak bersama yang sudah ada sebelumnya, tapi hanya harapan akan kemungkinan kesepakatan. Atau bila terjadi ketidaksepakatan, sekurang-kurangnya yang menarik dan berguna.

\section{Pengetahuan dan Kebenaran}

Anti-fondasionalisme Rorty menolak bahwa justifikasi atas klaim-klaim pengetahuan harus atau dapat berakhir di kepercayaankepercayaan atau pernyataan-pernyataan yang menyediakan suatu fondasi bagi pengetahuan. Rorty tidak berpikir bahwa pengetahuan memiliki struktur menyeluruh tertentu lainnya. Dalam pandangan Rorty, seseorang menjustifikasi suatu kepercayaan atau pernyataan dengan mengemukakan kepercayaan-kepercayaan atau pernyataanpernyataan lainnya yang tidak menyaratkan justifikasi dalam konteks itu. Konsekuensinya, Rorty menolak skeptisisme sebagai suatu masalah bagi filsafat dan menolak juga teori-teori yang pertimbangannya adalah bahwa teori-teori dimaksud memiliki isi untuk menyelesaikan masalah skeptisisme. Anti fondasionalisme Rorty juga menolak bahwa terdapat sejumlah disiplin tertentu atau bagian dari budaya yang memiliki peran untuk menyediakan justifikasi, atau membuat pengertian tentang. Rorty khususnya berkeras bahwa adalah sebuah kesalahan untuk mencoba menjustifikasi praktik-praktik dan institusi-institusi seperti demokrasi liberal, kemerdekaan akademis dan penelitian ilmiah dengan menarik teori-teori filsafat yang memperlihatkannya berkaitan dengan kodrat akhir realitas atau manusia sendiri atau keinginan Tuhan atau sesuatu yang lebih besar atau mendalam daripada praktik-praktik aktual. Ini bukanlah pandangan bahwa praktik-praktik seperti itu tidak memerlukan justifikasi tertentu, namun lebih karena justifikasi-justifikasi yang tepat akan selalu sedikit demi sedikit dan lokal. ${ }^{10}$

Rorty menolak bahwa terdapat teori tertentu tentang kebenaran, yakni perhitungan umum tertentu atas apa yang

${ }^{10}$ Rohr, “Richard McKay Rorty”..., h. 19. 
membuat kepercayaan-kepercayaan dan kalimat-kalimat adalah benar. Rorty menolak teori-teori korespondensi dan teori-teori koherensitentangkebenaran.Antirepresentasionalismenyamenolak bahwa esensi tentang bahasa adalah untuk merepresentasikan atau menggambarkan realitas. Rorty menolak baik realisme ataupun antirealisme (atau idealisme) sebagai produk-produk dari suatu pandangan representasional yang salah jalan atas bahasa. Tidak ada kelas kebenaran yang memiliki status fondasional terkait sisa kebenaran. Sementara kepercayaan-kepercayaan seringkali disebut benar ketika kepercayaan-kepercayaan dijustifikasi dengan lebih baik daripada yang lainnya. Benar tidak berarti dijusifikasi atau dijamin. Benar tidak dapat didefinisikan dan dieliminasi. ${ }^{11}$

Karena tidak ada fondasi bagi kebenaran atau pengetahuan, maka tidak adayang diluar praktik-praktiksosialyang mendasarinya. Oleh karenanya, Rorty terkadang menolak objektivitas sebagai suatu tujuan dari penyelidikan terkait solidaritas dengan komunitas penyelidikan. Rorty mendorong bahwa objektivitas dipahami sebagai intersubjektivitas atau sebagai singkatan untuk praktik-praktik, seperti tidak makan suap, yang ditemukan sangat membantu dalam sebagian besar dari penyelidikan. Rorty seringkali dituduh relativisme dan tuduhan ini ditolak Rorty. Rorty mengklaim bahwa relativisme tentang kebenaran mudah untuk ditolak. Alternatif bagi relativisme tentang justifikasi bahwa Rorty mendukung etnosentrisme, pandangan bahwa jusifikasi adalah relatif bagi praktik-prraktik. Pembelaan atas kepercayaan-kepercayaan melawan tantangan-tantangan oleh komunitas-komunitas lainnya harus selalu merupakan pertanyaan yang dipinta, namun ini tidak melemahkan pembelaan, karena tidak ada jenis pembelaan lain yang lebih baik atau bahkan sama baiknya, dan penilaian harus selalu merupakan lawan alternatif yang relevan. ${ }^{12}$

\section{Pikiran dan Masyarakat}

Sebagai seorang filsuf sosial, Rorty mengembangkan dua jalur pemikiran yang berbeda. Pada satu sisi, Rorty adalah seorang demokrat liberal burjuis yang merayakan akhir ideologi dan membela meliorisme tambahan. Pada sisi lain, Rorty berusaha

\footnotetext{
${ }^{11} \mathrm{Ibid}$, ..., h. 21.

${ }^{12} \mathrm{Ibid}$, ..., h. 27.
} 
untuk menjaga utopianisme imaginatif. Ini menjadikan Rorty target para pemikir politik dari semua titik spektrum politik yang menyalahkannya karena memberikan kenyamanan bagi musuh. ${ }^{13}$

Dalam filsafat pemikiran, Rorty berbicara tentang kepercayaan, hasrat, dan sebagainya sebagai cara pembicaraan yang berguna untuk memprediksi, mengontrol, berimajinasi dan membuat pengertian tentang sesuatu yang dilakukan, sebagaimana fisika dan neurologi memberikan cara-cara pembicaraan yang berguna untuk memprediksi dan sebagainya. Tidak satupun dari ini yang utama atau perlu direduksi bagi yang lainnya, meskipun tidak perlu beranggapan bahwa ketika menyebutkan kepercayaankepercayaan dan keinginan-keinginan seseorang dibicarakan tentang sesuatu yang lain daripada apa yang dibicarakan tentang ketika menyebutkan proses-proses syarafnya (fisikalisme yang tidak reduktif). Pikiran sebagai sebuah subjek filosofis dibawa Rorty menjadi suatu fiksi yang sangat besar disusun oleh Descartes keluar dari pemikiran-pemikiran dan sensasi-sensasi. Para filsuf seharusnya tidak membicarakan pikiran, karena membingungkan dan tidak membantu. Banyak bagian dalam pemikiran Rorty yang telah diabaikan dalam sketsa terdahulu, yakni pergulatannya dengan filsafat sebagai sebuah profesi, ide-idenya dalam historiografi filsafat dan serangan-serangannya terhadap sosalisme. Rorty telah memperlihatkan kebajikan-kebajikan tentang kerendahan hati dan keinginan untuk belajar dari kritikan yang simpatik, dan Rorty telah memodifikasi dan memperluas pemikirannya. ${ }^{14}$

\section{Kritik Richard Rorty atas Fondasionalisme}

Para filsuf alam Yunani kuno mengemukakan berbagai macam prinsip dasar alam semesta. Contohnya, Thales menyebutkan air, Anaximander apheiron, Anaximenes udara, dan Pythagoras bilangan. Pemikiran tentang dasar alam semesta ini dikembangkan lagi oleh Herakleitos yang mengatakan bahwa dasar alam semesta yang sejati adalah perubahan. Herakleitos mengeluarkan diktum yang terkenal bahwa "segala sesuatu mengalir" (pantha rei kei onden menei). Herakleitos kemudian mengemukakan konsep logos sebagai

${ }^{13} \mathrm{Ibid}, \ldots$, h. 32 .

${ }^{14} \mathrm{Ibid}, \ldots$, h. 33. 
sesuatu yang konsisten yang mendasari segala perubahan tersebut. Logos yang dikemukakan Herakleitos merupakan usahanya untuk memecahkan masalah filosofis berikut: bagaimana manusia dapat memiliki pengetahuan bila segala sesuatu terus berubah? Dunia sebagaimana dialami manusia secara inderawi adalah dunia yang terus berubah dan menurut Herakleitos di balik perubahan tersebut pasti ada sesuatu yang tetap, permanen, dan universal. Manusia tidak bisa mempercayai begitu saja pengalaman indrawinya melainkan harus menggunakan akalnya yaitu satu-satunya bagian dalam benak manusia yang dapat mengenali logos. Akallah satusatunya bagian yang mampu menemukan ketetapan pada segala sesuatu yang berubah. ${ }^{15}$

Tradisi filsafat Barat di atas kemudian dilanjutkan oleh Descartes, Locke dan Kant dengan sedikit perbedaan. Descartes dengan metode kesangsian yang berujung pada rumusan cogito, ergo sum. Locke yang berpendapat bahwa pikiran bagaikan tabula rasa yang diisi sensasi. Kant dengan pemisahan antara noumena dan fenomena. ${ }^{16}$ Mereka tidak lagi memiliki fokus pada dasar alam semesta melainkan pada dasar pengetahuan manusia tentang semesta.

Descartes, Locke dan Kant membuat aturan-aturan epistemik yang mutlak sifatnya bagi keabsahan pengetahuan manusia. Descartes menyatakan bahwa pengetahuan manusia harus berupa kepastian matematis yang sifatnya bawaan di benak manusia yang tidak diasalkan dari persepsi indrawi. Karena benak manusia mampu mengenali ide-ide yang jernih dan terpilah dan manusia merupakan subyek berkesadaran dari semesta eksternal yang berkeluasan, maka benak manusia merupakan representasi internal dari semesta eksternal. Locke, mengatakan bahwa pengetahuan manusia harus berasal dari sensasi empiris yang kemudian menjadi ide di benak manusia berdasarkan prinsip asosiasi, kemiripan dan identitas. Sementara Kant menggagas bahwa pengetahuan manusia merupakan hasil konstruksi kategori-kategori terhadap pencerapan inderawi dan bersandar pada satu ego transendental. Proyek

${ }^{15}$ Adian, Menyoal Objektivisme Ilmu..., h. 94-96.

${ }^{16}$ A.M.W. Pranarka, Epistemologi Dasar: Suatu Pengantar, (Jakarta: CSIS, 1987), h. 126-139. 
epistemologis Descartes, Locke dan Kant mencapai puncaknya pada positivisme. Fondasi pengetahuan yang disodorkan positivisme adalah doktrin kesatuan ilmu. Doktrin yang mengklaim bahwa semua pengetahuan harus mengikuti model ilmu-ilmu alam yang bersifat eksplanatoris dan prediktif. Salah satu demarkasi ilmu dan non-ilmu adalah penggunaan bahasa dan metode ilmiah. Ini yang kemudian banyak memancing reaksi kritis para filsuf antifondasionalisme, ${ }^{17}$ termasuk tentunya Rorty.

Dalam buku Philosophy and the Mirror of Nature, Rorty menjelaskan bahwa fondasionalisme Locke, Descartes dan Kant pada dasarnya merupakan suatu pembakuan epistemik tentang proses mental yang terjadi dalam akal budi. Mereka berkeyakinan bahwa benak manusia mampu memperoleh gambaran obyektif apabila melepaskan diri dari kebersatuan sosial. Mereka mengabaikan interaksi sosial sebagai justifikasi kebenaran dan memandangnya sebagai elemen yang distortif. ${ }^{18}$

Tradisi filsafat Barat seperti memiliki benang merah epistemologis yang mengharuskan seseorang untuk melepaskan diri dari sosialitas dan solidaritas demi obyektivitas ilmu. Kebenaran menurut tradisi filsafat Barat bukan sekadar kesepakatan sementara melainkan harus berkorespondensi dengan semesta obyektif.

Aturan epistemik yang ditetapkan para filsuf di atas, sebenarnya memuat suatu asumsi ontologis yang sama. Mereka masih terkurung dalam mitos keterberian semesta. Perspektif ontologis mereka memperlihatkan adanya semesta yang berdiri independen di luar representasi konstruksi manusia. Semesta yang diyakini Descartes, Locke dan Kant adalah semesta mekanismatematis yaitu semesta yang bekerja seperti bekerjanya jam yang penuh keteraturan matematis.

Rorty menekankan sikap antifondasionalismenya dengan mengadopsi ide Pragmatisme bahwa aturan-aturan epistemologis pada dasarnya merupakan permasalahan praktik-praktik sosial. Pragmatisme mengganti korespondensi dengan kesepakatan sosial, pengetahuan manusia bukanlah suatu cermin semesta melainkan

\footnotetext{
${ }^{17}$ Adian, Menyoal Objektivisme Птmu..., h. 96-97.

${ }^{18} \mathrm{Ibid}, \ldots$, h. 97.
} 
hasil proses interaksi manusia dan semesta yang legitimasinya tidak berangkat dari kegiatan individual melainkan sosial. Justifikasi adalah permasalahan praktik sosial karena "bagaimana seseorang mengatakan ini adalah kebenaran tanpa adanya orang lain untuk membenarkannya?" Rorty menekankan prioritas pada publik ketimbang privasi. Individu tidak memiliki ego transendental yaitu ego yang terlepas-berjarak dari sosialitasnya. Individu adalah bentukan komunitas di mana ia tinggal yang menentukan rutinitas, keterbiasaan dalam menentukan yang benar dan salah. Seperangkat aturan yang telah disepakati secara sosial dan menjadi tradisi disebut Rorty bentuk-bentuk kehidupan (forms of life). Manusia hidup, bertindak dan berpikir di dalam sistem-sistem di mana kita tersosialisasikan ke dalamnya, sistem-sistem yang secara pasif diinternalisasikan dan belajar untuk meletakkan kepercayaan. Semesta tidak ada yang terberi melainkan konstruksi bentuk kehidupan yang pluralistik. Rorty menolak patokan kebenaran ilmu pengetahuan sebagai kebenaran tunggal tentang semesta. Kebenaran harus diukur bukan berdasarkan satu patokan epistemik yang universal dan transendental melainkan berdasarkan bentuk kehidupan masing-masing komunitas. ${ }^{19}$

Rorty juga mengeritisi bahan ilmiah sebagai kriteria demarkasi ilmu dan non-ilmu yang dinyatakan Positivisme. Dalam esai World Well Lost, Rorty menyatakan bahwa semesta tidaklah terberi melainkan selalu termediasi oleh bahasa. Suatu pendekatan aprioristik terhadap semesta adalah sia-sia karena semesta sejati tidak pernah diketahui. Ide Rorty akan ketersembunyian hakikat semesta telah memberi tempat pada pluralisme representasi karena tidak ada suatu representasi pun yang memiliki akses utama terhadap semesta. Keterpisahan bahasa dan semesta yang dikemukakan kaum positivisme logis menurut Rorty merupakan suatu yang tidak mungkin. Tidak dapat diketahui "apa di luar sana atau apa di dalam sini” tanpa dimediasi oleh bahasa yang telah disepakati secara sosial. ${ }^{20}$

Gagasan bahwa bahasa mengonstruksisemesta dan bukannya merepresentasikannya tidak sama dengan gagasan Kant bahwa

\footnotetext{
${ }^{19}$ Ibid..., h. 98-99.

${ }^{20} \mathrm{Ibid...,} \mathrm{h.} 99$.
} 
kategori-kategori mengonstruksi pengalaman empiris menjadi pengetahuan. Ke-12 kategori Kant secara implisit mengandung asumsi semesta sebagai keteraturan yang membuatnya terjebak pada mitos keterberian semesta. Hal ini tentu saja berseberangan dengan ide Rorty tentang ketersembunyian semesta yang membuka jalan bagi pluralitas bentuk kehidupan. Bahasa merupakan hasil kesepakatan sosial berupa deskripsi yang tidak permanen melainkan terus berevolusi. Berbagai versi tentang obyek, benda, dunia muncul dari berbagai komunitas sebagai respon terhadap problematika tertentu, upaya untuk mengatasi situasi tertetu, dan alat untuk memuaskan kebutuhan dan kepentingan tertentu. Sederhananya, ide, kata, dan bahasa bukan cermin yang merepresentasikan semesta melainkan alat untu beradaptasi dengan lingkungan komunitas. Suatu deskripsi yang lebih bermanfaat bagi suatu komunitas untuk menyelesaikan masalah, kebutuhan, dan kepentingan untuk sementara memperoleh legitimasi sebagai kebenaran. ${ }^{21}$

Permasalahan kebenaran bukan lagi permasalahan fondasi maupun korespondensi melainkan permasalahan kesepakatan lokal dalam setiap komunitas. Pluralisme kebenaran harus terus dijaga agar jangan terjebak kembali dalam suatu ide tentang fondasi akan menegasikan representasi-representasi yang berada di luar fondasi yang ditetapkan (the other). Untuk itu, filsafat harus meninggalkan arogansinya dalam memberikan fondasi bagi berbagai disiplin ilmu dan kebudayaan. Rorty melalui buku Philosophy dan the Mirror of Nature sebenarnya ingin mengatakan bahwa ideologi fondasionalistik harus segera dikuburkan untuk memulai babakan baru epistemologi sebagai percakapan antara pluralitas kebenaran. Epistemologi yang menghermeneutika. Sebuah babakan baru yang hanya mungkin bila filsafat rela menanggalkan hak-hak istimewanya. ${ }^{22}$

\section{E. Evaluasi atas Kritik Richard Rorty}

Dalam pandangan Rorty, epistemologi sesungguhnya muncul dan berkembang subur atas dasar beberapa kerancuan yang telah menandainya sejak awal. Kerancuan pertama, sebagaimana terlihat dalam pemikiran Locke, adalah kerancuan antara syarat-

${ }^{21}$ Ibid..., h. 99-100.

${ }^{22}$ Ibid..., h. 100. 
syarat penjelasan atau penyebaban munculnya pengetahuan dan pembenaran terhadapklaim pengetahuan.Lockeberanggapan bahwa dari adanya impresi dalam pikiran manusia tentang adanya sebuah segi tiga merah, dibuktikan bahwa sebuah benda yang berwarna merah dan berbentuk segi tiga sungguh ada di luar pikiran manusia. Kerancuan kedua, terlihat dalam pemikiran Kant, adalah kerancuan antara predikasi dan sintesis. Menurut Rorty, Kant benar ketika memahami pengetahuan sebagai suatu yang berkenaan dengan proposisi dan bukan dengan benda atau objek pada dirinya sendiri di luar pikiran. Akan tetapi, Kant keliru ketika mengklaim bahwa konsep merupakan pemaduan (pembuatan sintesis) secara apriori atas intuisi inderawi yang masih bersifat pusparagam. Klaim yang dibuat oleh Kant - bahwa keniscayaan kebenaran dalam putusan sintesis apriori didasarkan atas deduksi logis aktivitas akal budi yang membentuk suatu objek - hanya dapat diterima kalau asumsi Descartes bahwa kebenaran rasional lebih terjamin kepastiannya daripada kebenaran empiris. ${ }^{23}$

Epistemologi modern yang mulai dengan upaya Descartes menjamin kepastian pengetahuan dengan melakukan kajian tentang pikiran manusia sendiri - suatu upaya yang kemudian dilanjutkan oleh Locke dengan kajiannya tentang cara kerja pikiran dalam proses mengetahui dan akhirnya disempurnakan oleh Kant dengan analisisnya tentang apa yang ia nyatakan sebagai syaratsyarat yang secara niscaya diperlukan untuk dimungkinkannya pengetahuan apa pun - didasarkan atas gambaran pengetahuan sebagai representasi realitas atau penyajian kembali objek di luar manusia.

Pengetahuan dalam epistemologi modern selalu dimaksudkan sebagai pengetahuan tentang objek tertentu (knowledge of) di luar manusia, dan bukan pengetahuan bahwa (knowledge that) sesuatu ini begini atau begitu. Pengetahuan tidak dimengerti sebagai justified true belief, tapi sebagai accurate representation of reality. Pengandaian ini mengandaikan kebenaran teori kebenaran yang disebut teori korespondensi, dan paham mengetahui sebagai melihat serta melaporkan sesuatu di luar pikiran secara akurat.

${ }^{23}$ J. Sudarminta, Epistemologi Dasar: Pengantar Filsafat Pengetahuan, (Yogyakarta: Kanisius, 2002), h. 24. 
Menurut Rorty, seluruh gagasan tentang epistemologi sebagai upaya rasional untuk membangun fondasi atau dasar-dasar pengetahuan merupakan produk pilihan metafor "melihat atau metafor “"cermin" untuk kegiatan mengetahui. Apabila pilihan metafor ini ditinggalkan, maka tidak perlu lagi orang berpikir tentang perlunya fondasi untuk pengetahuan. Kalau keperluan akan pendasaran pengetahuan tidak ada lagi atau tidak lagi dibutuhkan, maka epistemologi sebagai upaya memberi pendasaran pengetahuan juga tidak perlu lagi. Bagi Rorty, keinginan untuk mengembangkan epistemologi berangkat dari keperluan akan adanya dasar yang kokoh dan tidak tergoyahkan bagi pengetahuan. Hasrat ini merupakan hasrat yang tidak mungkin terpenuhi, karena melawan kontingensi atau keterbatasan pengetahuan manusia. Klaim bahwa itu mungkin, bersifat menipu diri. Tidak ada tolok ukur lain bagi objektivitas kebenaran pengetahuan manusia kecuali praksis sosial tempat pengetahuan itu dikemukakan. Demikian argumen Rorty untuk menujukkan bahwa epistemologi tidak diperlukan lagi. Yang diperlukan sekarang adalah hermeneutika, yakni aktivitas pemaknaan wacana dalam percakapan budaya umat manusia. Hermeneutika memahami hubungan antara macam-macam aspek kebudayaan atau macam-macam wacana sebagai alur-alur percakapan yang mungkin dilakukan. ${ }^{24}$

Rorty sebenarnya telah memahami epistemologi secara sempit, yakni terbatas pada pengertian epistemologi fondasional sebagaimana dimaksud oleh Descartes, Locke dan Kant. Epistemologi dimengerti sebagai upaya rasional untuk memberi dasar yang kokoh tidak tergoyahkan dan bersifat ahistoris.

Descartes, Locke dan Kant memahami mengetahui sebagai kegiatan merepresentasikan seobyektif mungkin apa yang ditangkap secara indrawi dari luar, bagaikan cermin yang semakin bersih semakin mampu memantulkan kembali benda-benda di luar dirinya secara tepat. Apabila epistemologi dan kegiatan manusia mengetahui dimengerti seperti itu, memang tidak lagi memadai. Akan tetapi, epistemologi dan kegiatan manusia mengetahui tidak harus dimengerti seperti itu. Epistemologi pada dasarnya merupakan suatu kajian filosofis - menggeluti masalah umum,

${ }^{24}$ Sudarminta, Epistemologi Dasar: Pengantar..., h. 24-25. 
menyeluruh, dan mendasar - tentang pengetahuan. Dalam arti ini, apa yang dibuat Rorty sendiri dapat digolongkan sebagai suatu epistemologi. Kemudian pandangan Rorty bahwa kegiatan mengetahui itu tidak sama dengan melihat dan melaporkan kembali atau merepresentasikan apa yang dilihat, kiranya pantas disetujui. Akan tetapi, epistemologi justru diperlukan untuk menunjukkan bahwa paham seperti itu tidak tepat. Epistemologi sebagai suatu bentuk fondasionalisme sebagaimana dikembangkan oleh Kant memang tidak sesuai dengan sifat historis dan contingent pengetahuan manusia. Akan tetapi, ini tidak berarti bahwa segala bentuk epistemologi akan jatuh ke fondasionalisme model Descartes, Locke dan Kant sebagaimana Rorty khawatirkan. Maka, tidak benar bahwa epistemologi menjadi tidak perlu dan bahkan tidak mungkin lagi dikembangkan. Bagaimanapun juga, manusia sebagai makhluk rasional akan selalu terdorong untuk mencari dasar pijak - yang barangkali masih dapat direvisi kemudian - yang paling tidak untuk sementara waktu dapat dijadikan sebagai acuan pertanggungjawaban klaim kebenaran pengetahuannya. Apabila praksis sosial yang dalam kenyataan berlaku dalam lingkungan masyarakat tertentu dijadikan dasar terakhir penilaian, kemudian bagaimana praksis sosial itu sendiri mau dinilai? ${ }^{25}$

\section{F. Penutup}

Penolakan Rorty terhadap epistemologi adalah bentuk kritikan Rorty atas epistemologi fondasional yang berakar pada pandangan-pandangan Descartes, Locke, dan Kant. Epistemologi memang memiliki kelemahan ketika hanya dimengerti sebagai usaha untuk memberi dasar bagi segala sesuatu, termasuk pengetahuan. Epistemologi juga tidak tepat bila hanya dipahami sebagai kegiatan untuk menampikan seobyektif mungkin apa yang ditangkap secara inderawi dari luar. Akan tetapi, epistemologi sebenarnya tidak harus dimengerti secara sempit seperti pemahaman Rorty. Dalam pengertian yang lebih luas, Rorty sendiri sesungguhnya sedang berepistemologi ketika dia juga berkecimpung dalam dunia pengetahuan[].

${ }^{25}$ J. Sudarminta, Epistemologi Dasar: Pengantar Filsafat Pengetahuan, (Yogyakarta: Kanisius, 2002), h. 25-26. 


\section{Daftar Pustaka}

Adian, Donny Gahral, Menyoal Objektivisme Ilmu Pengetahuan: dari David Hume sampai Thomas Kuhn, Bandung: Teraju, 2002.

Godefrey-Smith, Peter, An Introduction to the Philosophy of Science: Theory and Reality, Chicago: the University of Chicago Press, 2003.

Martinich, A.P. dan Sosa, David (ed), A Companion to Analytic Philosophy, Massachusetts: Blackwell Publisher Inc., 2001.

Mudhofir, Ali, Kamus Filsafat Barat, Yogyakarta: Pustaka Pelajar, 2001.

Pranarka, A.M.W., Epistemologi Dasar: Suatu Pengantar,(Jakarta: CSIS, 1987.

Rorty, Richard, Philosophy and the Mirror of Nature, NJ: Princeton University Press, 1979.

Routledge Encyclopedia of Philosophy, Version 1.0, London and New York: Routledge, 1998.

Sim, Stuart, The Routledge Companion to Postmodernism, London and New York: Routledge, 2001.

Sudarminta, J., Epistemologi Dasar: Pengantar Filsafat Pengetahuan, Yogyakarta, Kanisius, 2002.

Sugiharto, I. Bambang, Postmodernisme: Tantangan bagi Filsafat, Yogyakarta, Kanisius, 1996. 